\title{
Release of contaminants from continental surface sediment: the importance of mineralogical composition and organic matter degradation
}

CECILE GROSBOIS ${ }^{1}$, NATHALIE GASSAMA ${ }^{1}$, MYKYTA SHUMSKIKH $^{1}$, MENGXUE ZHANG ${ }^{1}$, CASSANDRE LAZAR $^{2}$ AND MARC DESMET ${ }^{1}$

${ }^{1}$ University of Tours

2-Université du Québec

Presenting Author: cecile.grosbois@univ-tours.fr

Surface sediments are usually considered as a sink for hydrophobic contaminants (trace elements and organic components). However, river floods, dredging and dam maintenance operations can modify their storage and transport conditions leading to their release to the sediment-water interface and then to surface waters.

To assess contaminant mobility to the water column under hydrological and redox variations, batch experiments over 30 days were carried out on sediments highly enriched in trace elements, PAH and PCB (Bertrand et al, 2015; Dhivert et al, 2016; Dendeviel et al, 2020). Four experimental set-ups were designed to distinguish the importance of biotic from abiotic mechanisms: on raw and on g-irradiated sediments, under oxic and anoxic $\left(\mathrm{N}_{2}\right.$ atmosphere) conditions.

Time evolution of dissolved major elements, organic $\mathrm{C}, \mathrm{N}$ and $\mathrm{P}$ concentrations in the leachates emphasized the main influence of biological activity and mineralogical composition of sediments on contaminant mobility. If $\mathrm{pH}$ seems to be the main factor controlling mineral dissolution, the nature of microorganisms involved in organic matter degradation (different for aerobic and anaerobic experiments) had also an important influence. For g-irradiated sediments, some resistant bacteria reactivated after $24 \mathrm{~h}$ of experiment. This demonstrated that g-radiation such as other sterilization methods kill some classes of microorganisms but not all and it increases the quantity of easily degradable organic matter.

Although studied sediments were not particularly enriched in As, Cd, Co, Ni, Zn and tri-butyl phosphate, the leachates (raw sediment under both conditions) mainly contained these contaminants (PAH and PCB under LD). Registered concentration maxima were higher than bottom water ones and French EQS limits. 